\title{
New species of Guidus Ivanov, 2006 (Cestoda: Phyllobothriidea) from Bathyraja magellanica (Philippi) from the Patagonian Continental Shelf of Argentina
}

\author{
Adriana Menoret ${ }^{1,2}$ and Verónica A. Ivanov ${ }^{1,2,3}$ \\ ${ }^{1}$ Instituto de Biodiversidad y Biología Experimental y Aplicada (IBBEA, CONICET-UBA), Facultad de Ciencias Exactas y \\ Naturales, Universidad de Buenos Aires, Ciudad Autónoma de Buenos Aires, Argentina; \\ ${ }^{2}$ Consejo Nacional de Investigaciones Científicas y Técnicas, Argentina; \\ ${ }^{3}$ This paper is dedicated to the memory of the late Verónica Ivanov with whom the first author started writing the manuscript.
}

\begin{abstract}
Specimens representing two new species of Guidus Ivanov, 2006 were collected from the Magellan skate (Bathyraja magellanica [Philippi]) in the Patagonian Continental Shelf of Argentina, Southwestern Atlantic Ocean. Guidus francoi sp. n. and Guidus magellanicus sp. n. differ from their congeners by a particular combination of features, including type of bothridia, worm length, number of testes, and distribution of vitelline follicles. Guidus francoi sp. n. is distinguished from G. magellanicus sp. n. by having fewer proglottids, fewer testes and a higher ratio between the cirrus sac length and the proglottid width. The microthrix pattern of species of Guidus from the Southwestern Atlantic is described, based on specimens of G. francoi sp. n., Guidus magellanicus sp. n., and newly collected specimens of Guidus argentinense Ivanov, 2006. These three species share the presence of wide aristate gladiate spinitriches on the proximal bothridial surface, narrow gladiate spinitriches on the bothridial rim, and filitriches on the distal bothridial surface. The diagnosis of Guidus is revised to include several features exhibited by the new species (i.e., presence of bothridial indentations and bothridial stalks, distribution of vitelline follicles, and eggs grouped in cocoons). The discovery of G. francoi sp. n. and G. magellanicus sp. n. from B. magellanica increases the number of species of Guidus collected from batoids in the Southwestern Atlantic from one to three. The specificity exhibited by the species herein described reinforces the tight association between rays in the genera Guidus and Bathyraja.
\end{abstract}

Key words: Guidus francoi sp. n., Guidus magellanicus sp. n., morphology, description, SEM, Magellan skate, Arhynchobatidae, Argentinian Continental Shelf, Southwestern Atlantic Ocean.

The order Phylllobothriidea Caira, Jensen, Waeschenbach, Olson et Littlewood, 2014 is known to be cosmopolitan in distribution, with the majority of records from the Northern Hemisphere (Ruhnke 2011, Moghadam and Haseli 2019, Caira et al. 2020, Maleki et al. 2020). The order has been found in a diversity of definitive hosts including sharks, batoids and chimaeras. To date, most of the genera (11/18) within the order are known to be associated to a particular species, genus or family of shark (Ruhnke 2011, Ruhnke et al. 2017, 2020, Moghadam and Haseli 2019, Caira et al. 2020, Maleki et al. 2020).

Unlike most phyllobothriideans, members of Guidus Ivanov, 2006 are typically distributed in temperate and cold waters in the Southern Hemisphere and parasitise arhynchobatid skates of the genus Bathyraja Ishiyama (see Wojciechowska 1991, Rocka and Zdzitowiecki 1998, Ivanov 2006). Among the three valid species, Guidus awii
(Rocka et Zdzitowiecki, 1998) and Guidus antarcticus (Wojciechowska, 1991) were reported from Antarctic waters and described from the type host Bathyraja maccaini Springer, whereas Guidus argentinense Ivanov, 2006 was reported from lower latitudes off Argentina from Bathyraja brachyurops (Fowler) (see Wojciechowska 1991, Rocka and Zdzitowiecki 1998, Ivanov 2006).

During a parasite survey of batoids off the Argentinian Patagonian Shelf in the Southwestern Atlantic Ocean between $\sim 49^{\circ}-54^{\circ} \mathrm{S}$, tapeworms parasitising the Magellan skate, Bathyraja magellanica (Philippi), were recognised as members of the genus Guidus. Two new species of Gui$d u s$ are herein described based on detailed morphology of adult worms using light and scanning electron microscopy (SEM), and histological sections. Additionally, the bothridial surfaces of $G$. argentinense are studied with SEM for the first time, based on newly collected specimens.

Address for correspondence: Adriana Menoret, Instituto de Biodiversidad y Biología Experimental y Aplicada, (IBBEA, CONICET-UBA), Facultad de Ciencias Exactas y Naturales, Universidad de Buenos Aires, Ciudad Universitaria, Intendente Güiraldes 2160, Pabellón 2, Piso $4^{\circ}$. Ciudad Autónoma de Buenos Aires, Buenos Aires, Argentina (C1428EGA). E-mail: menoret.a@gmail.com. 


\section{MATERIALS AND METHODS}

Specimens examined in this study were collected from the intestine of nine Bathyraja magellanica and two Bathyraja brachyurops (Fowler) (Rajiformes: Arhynchobatidae) taken from different localities along the Argentine Sea. The specimens of $B$. magellanica were caught off Río Grande, Tierra del Fuego Province at 54.5082S, 65.2328W (assigned unique host number PD4-001) and 54.4033S, 63.9625W (PD4-025) in March 2012, 54.0279S, 67.1134W (PD4-097) in April 2012, 53.9293S, 67.0834W (PD10017) in March 2014, and 53.6042S, 67.6512W (PD10-070, PD10-071) and 53.9381S, 66.0790W (PD10-156) in April 2014; and off Puerto San Julián, Santa Cruz Province at 49.4938S, 66.1869W (PD7-105, PD7-107) in April 2013. Specimens of $B$. brachyurops were caught off Buenos Aires Province at 39.5713S, 56.2694W (PD3-285) in March 2011, and off the Namuncurá Marine Protected Area/Burdwood Bank at 54.7470S, 59.9476W (PD12-297) in April 2016. All hosts were caught with bottom trawls on board of the RV "Puerto Deseado" (CONICET).

All tapeworms were removed from the spiral intestine of their respective host, relaxed in seawater, fixed in $10 \%$ formalin and transferred to $70 \%$ ethanol for storage. The specimens prepared for light microscopy were hydrated in a graded ethanol series, stained with Harris haematoxylin, dehydrated in a graded ethanol series, cleared in methyl salicylate and mounted in Canada balsam. The terminal portion of four strobilae of specimens from $B$. magellanica was embedded in paraffin and serial cross sections were cut at a thickness of $7 \mathrm{~mm}$. Sections were stained with Harris hematoxylin, counterstained with eosin and mounted in Canada balsam. Gravid proglottids of specimens from $B$. magellanica were opened with insect pins to release the cocoons. Cocoons were mounted in lactophenol and sealed with nail polish.

Whole mounts, non-permanent mounts and histological sections were examined and measured using Olympus BX 51 and Zeiss Axioscope compound microscopes. Drawings were made with the aid of a drawing tube attached to the Olympus BX 51 compound microscope. Measurements are expressed as the range, followed in parentheses by the mean and standard deviation and the number of worms from which the measurements were taken. Measurements of genitalia were taken from mature proglottids of mature and gravid worms. All measurements are in micrometres unless otherwise stated.

Worms prepared for scanning electron microscopy (SEM) were hydrated in a graded ethanol series, post-fixed in $1 \%$ osmium tetroxide overnight at room temperature, dehydrated in a graded ethanol series, and dried using hexamethyldisilazane. After drying, the specimens were mounted on stubs with carbon tape, coated with $c .40 \mathrm{~nm}$ of gold/palladium with a Thermo VG Scientific Polaron SC 7630 and examined in either a Philips XL 30 or a Carl Zeiss NTS-SUPRA 40 scanning electron microscope.

Terminology for microthrix shape and size follows Chervy (2009). Valid host names follow Froese and Pauly (2020). Marine regionalisation follows Spalding et al. (2007). Museum abbreviation used are as follows: IP-
CAS, Institute of Parasitology, Academy of Sciences of the Czech Republic, České Budějovice, Czech Republic; MACN-Pa, Museo Argentino de Ciencias Naturales, Colección Parasitológica, Buenos Aires, Argentina.

\section{RESULTS}

Guidus francoi sp. n.

Figs. 1-3

ZooBank number for species:

urn:1sid:zoobank.org:act:1A016D65-7CA8-40A3-A2C6-818D397EC5E0

Description (based on 13 mature and 21 gravid whole worms, two mature and one gravid specimens examined with SEM, and cross sections of mature proglottids). Worms anapolytic; proglottids acraspedote. Specimens possessing mature proglottids 3.4-5.7 $(4.5 \pm 0.7, \mathrm{n}=13)$ mm long, 8-17 (12 $\pm 3, \mathrm{n}=13)$ proglottids per worm (Figs. 1A, 2A). Specimens possessing gravid proglottids $2.9-10.9(5.9 \pm 2.3, \mathrm{n}=21) \mathrm{mm}$ long, $8-24(13 \pm 4, \mathrm{n}=20)$ per worm (Fig. 1B,E). Maximum worm width at level of scolex (Fig. 1A,B). Scolex composed of scolex proper and 4 stalked bothridia, $445-1,050(689 \pm 141, \mathrm{n}=30)$ long, 450-1,087 (692 $\pm 137, \mathrm{n}=30)$ wide (Figs. 1A-D, 3A). Bothridia globose, conspicuously muscular, 365-1,012 $(530 \pm 129, \mathrm{n}=31)$ long, $175-345(268 \pm 48, \mathrm{n}=31)$ wide; with anteriorly-oriented apical aperture, continuous muscular sphincter, and apical sucker; anterior bothridial margin indented (Figs. 1A-D, 3A). Bothridial aperture 160$355(266 \pm 53, \mathrm{n}=28)$ diameter in apical view. Muscular sphincter encircling bothridial aperture, $12-25(16 \pm 3$, $\mathrm{n}=24)$ thick. Apical sucker on anterior margin of bothridium 49-92 $(69 \pm 12, \mathrm{n}=10)$ in diameter (Figs. 1C,D, 3B). Stalks short, 44-75 (59 $\pm 13, \mathrm{n}=4)$ long, 151-192 $(172 \pm 16, \mathrm{n}=8)$ wide (Figs. 1D, 3A,B). Cephalic peduncle absent. Neck, $1,170-4,430(2,224 \pm 804, \mathrm{n}=25)$ long, $110-210(157 \pm 28, \mathrm{n}=25)$ wide.

Apex of scolex proper covered with capilliform filitriches. Bothridial rim covered with narrow gladiate spinitriches interspersed with capilliform filitriches (Fig. 3B,I). Proximal bothridial surface covered with wide aristate gladiate spinitriches interspersed with capilliform filitriches; aristate gladiate spinitriches becoming shorter and wider more proximally (Fig. 3A,E,F,H). Distal bothridial surface covered with acicular to capilliform filitriches (Fig. 3G). Apical sucker surface covered with capilliform filitriches (Fig. 3J). Stalks covered with aristate gladiate spinitriches interspersed with capilliform filitriches, lacking spinitriches more proximally (Fig. 3B,D). Capilliform filitriches on neck and strobila arranged in scutes (Fig. 3A,C,K).

Specimens possessing mature proglottids with $7-16$ (11 $\pm 3, \mathrm{n}=13)$ immature proglottids, and single mature proglottid per worm (Fig. 1A). Terminal mature proglottid longer than wide, 610-865 $(755 \pm 82, \mathrm{n}=13)$ long, 270-360 (325 $\pm 30, \mathrm{n}=13)$ wide, length to width ratio 1.9-2.9 (2.3 $\pm 0.2, \mathrm{n}=13)$ : 1 (Figs. 1A, 2A). Specimens possessing gravid proglottids with 6-18 $(12 \pm 6, \mathrm{n}=20)$ immature proglottids, $1-2(1.5 \pm 0.5, \mathrm{n}=20)$ mature proglottids, and $1-5(2 \pm 1, \mathrm{n}=20)$ gravid proglottids per 


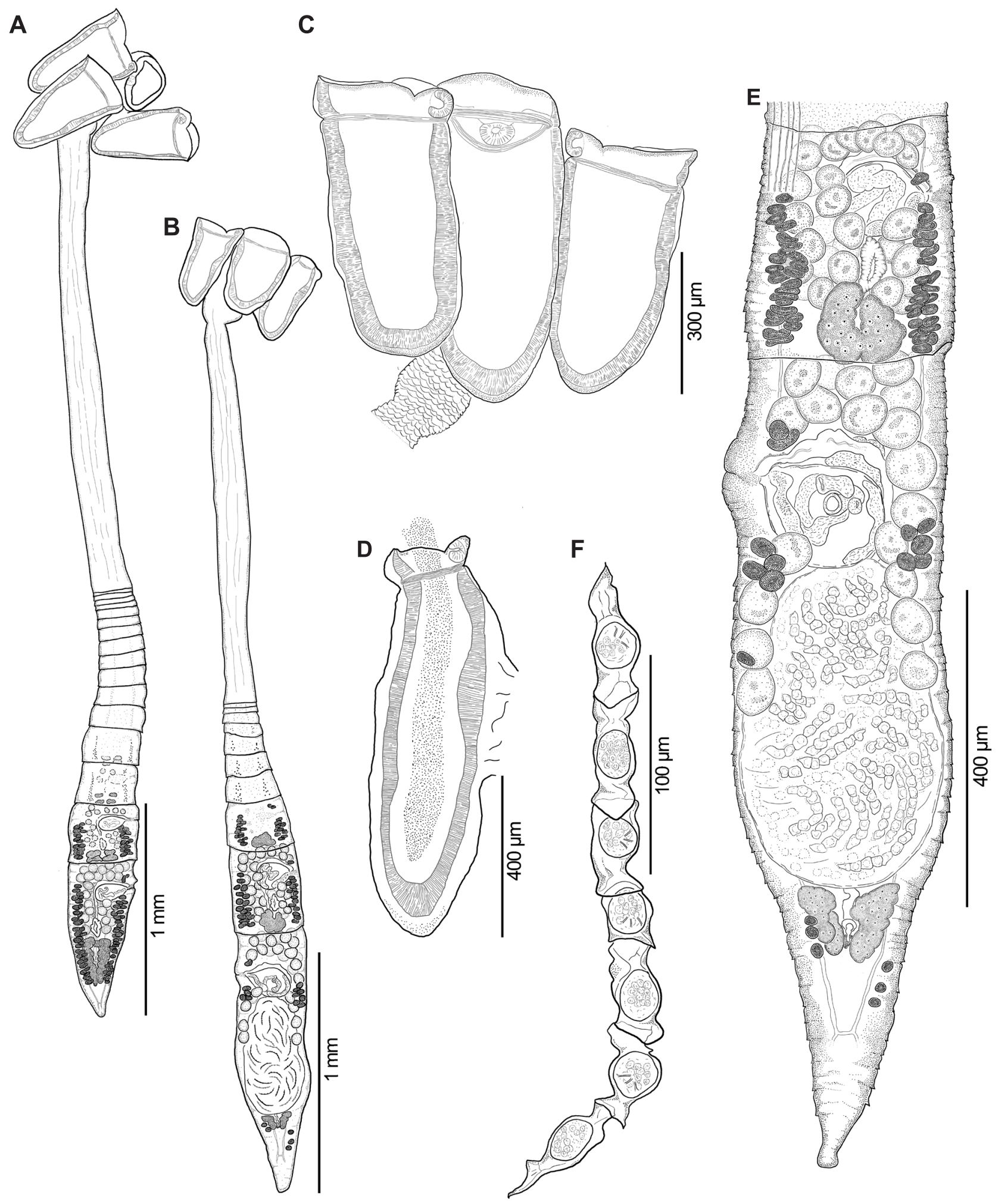

Fig. 1. Guidus francoi sp. n. from Bathyraja magellanica (Philippi), line drawings. A - entire mature worm (holotype MACN-Pa No. 739); B - entire gravid worm (paratype MACN-Pa No. 746/6); C - scolex (paratype MACN-Pa No. 743); D - bothridium attached to host tissue, muscular bothridial sphinchter contracted (paratype MACN-Pa No. 741/1); E - terminal portion of gravid strobila, ventral view (paratype MACN-Pa No. 746/6), longitudinal muscles partially drawn to allow the view of internal organs; $\mathbf{F}-$ cocoon.

worm. Posterior-most mature proglottids wider than long to longer than wide, $240-490(342 \pm 63, \mathrm{n}=21)$ long, $285-$ $605(406 \pm 83, \mathrm{n}=21)$ wide, length to width ratio $0.5-1.4$ $(0.9 \pm 0.3, \mathrm{n}=21): 1$. Subterminal gravid proglottids wider than long to longer than wide, 405-610 $(474 \pm 70, \mathrm{n}=8)$ long, 422-608 (513 $\pm 72, \mathrm{n}=8)$ wide, length to width ratio $0.7-1.3(1.0 \pm 0.2, \mathrm{n}=19)$ : 1 . Terminal gravid proglottid longer than wide, $700-1,338(993 \pm 166, \mathrm{n}=13)$ long, $300-550(416 \pm 67, \mathrm{n}=13)$ wide, length to width ratio 1.8-3.4 $(2.4 \pm 0.4, \mathrm{n}=13)$ : 1 (Figs. 1B,E, 3K). Testes oval, 
A

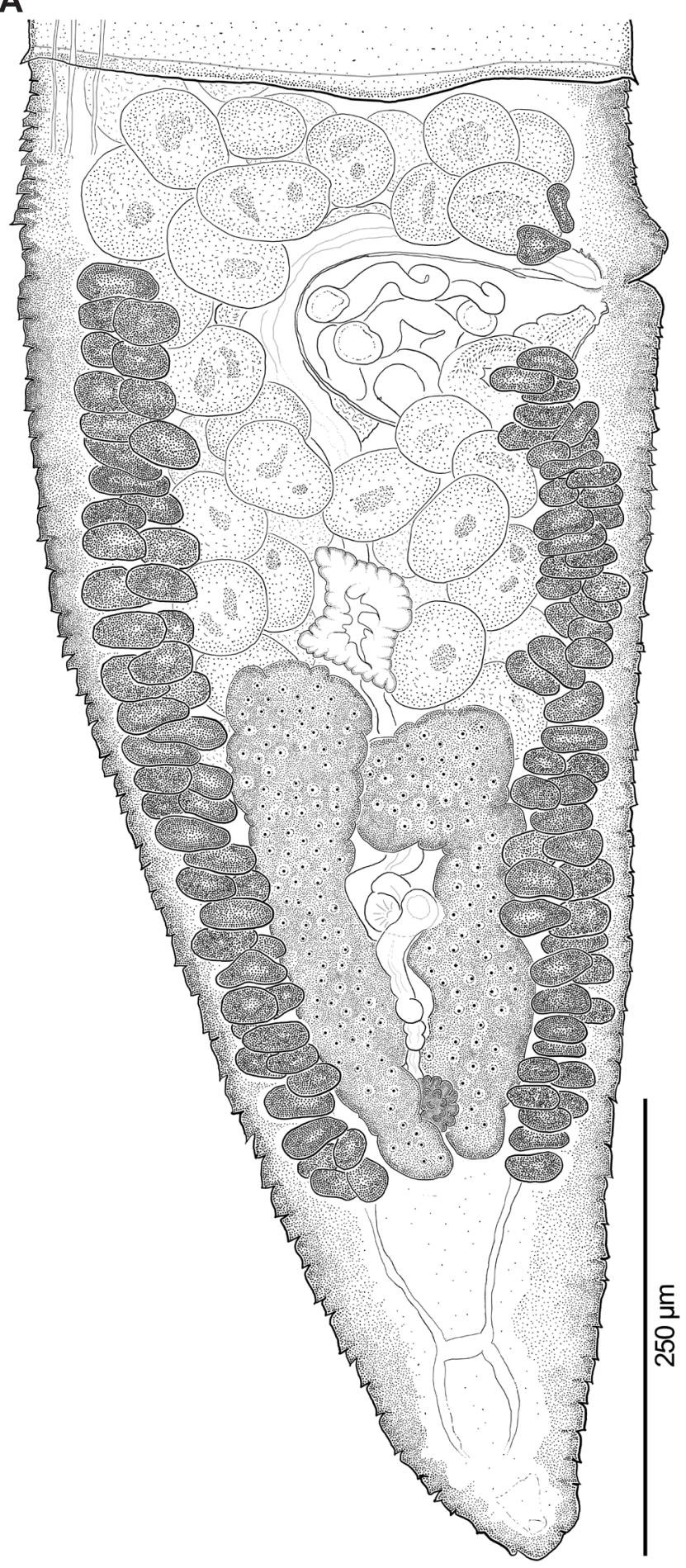

B
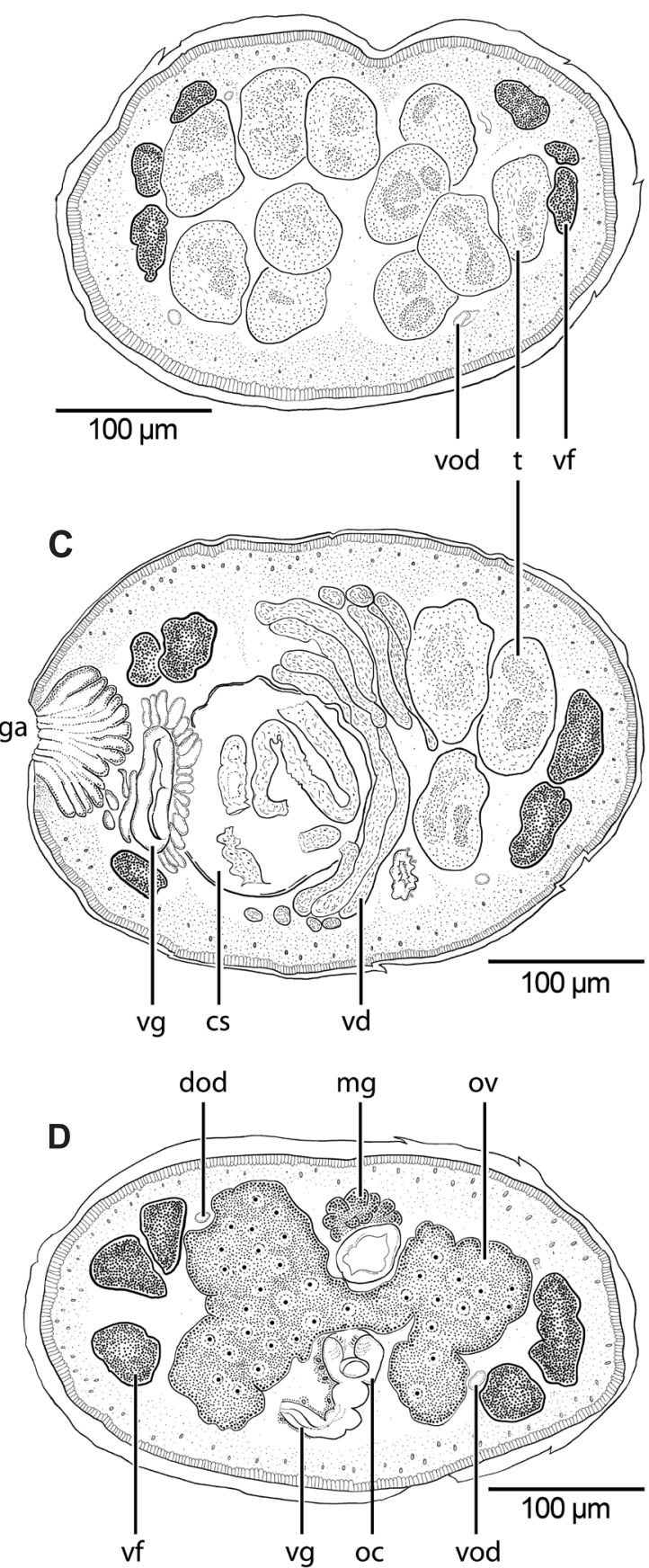

Fig. 2. Guidus francoi sp. n. from Bathyraja magellanica (Philippi), line drawings. A - terminal mature proglottid, ventral view (holotype MACN-Pa No 739), longitudinal muscles partially drawn to allow the view of internal organs; B - cross section of terminal mature proglottid at level of testes anterior to cirrus sac; $\mathbf{C}$ - cross section of terminal mature proglottid at level of genital atrium; $\mathbf{D}$ - cross section of terminal mature proglottid at level of ovarian isthmus. Abbreviations: cs - cirrus sac, dod - dorsal osmoregulatory duct, ga - genital atrium, mg - Mehlis' gland, oc - ovicapt, ov - ovary, $\mathrm{t}$ - testis, vd - vas deferens, vf - vitelline follicle, vg - vagina, $\operatorname{vod}$ - ventral osmoregulatory duct.

42-68 (52 $\pm 7, \mathrm{n}=31)$ long, 38-51 $(45 \pm 5, \mathrm{n}=31)$ wide, arranged in 4-5 columns dorsoventrally and in 2-3 layers deep in cross section; $42-68(53 \pm 6, \mathrm{n}=33)$ in number; extending from anterior margin of proglottid to anterior margin of ovary (Figs. 1E, 2A-C). Cirrus sac oval, 118-230
(163 $\pm 25, \mathrm{n}=34)$ long, 80-150 (116 $\pm 19, \mathrm{n}=34)$ wide, cirrus sac length to proglottid width ratio $0.4-0.6(0.5 \pm 0.1$, $\mathrm{n}=34)$ : 1 . Cirrus covered with minute spinitriches. Vas deferens coiled, extending from anterior margin of vagina to posterior margin of cirrus sac (Figs. 1E, 2A,C). 

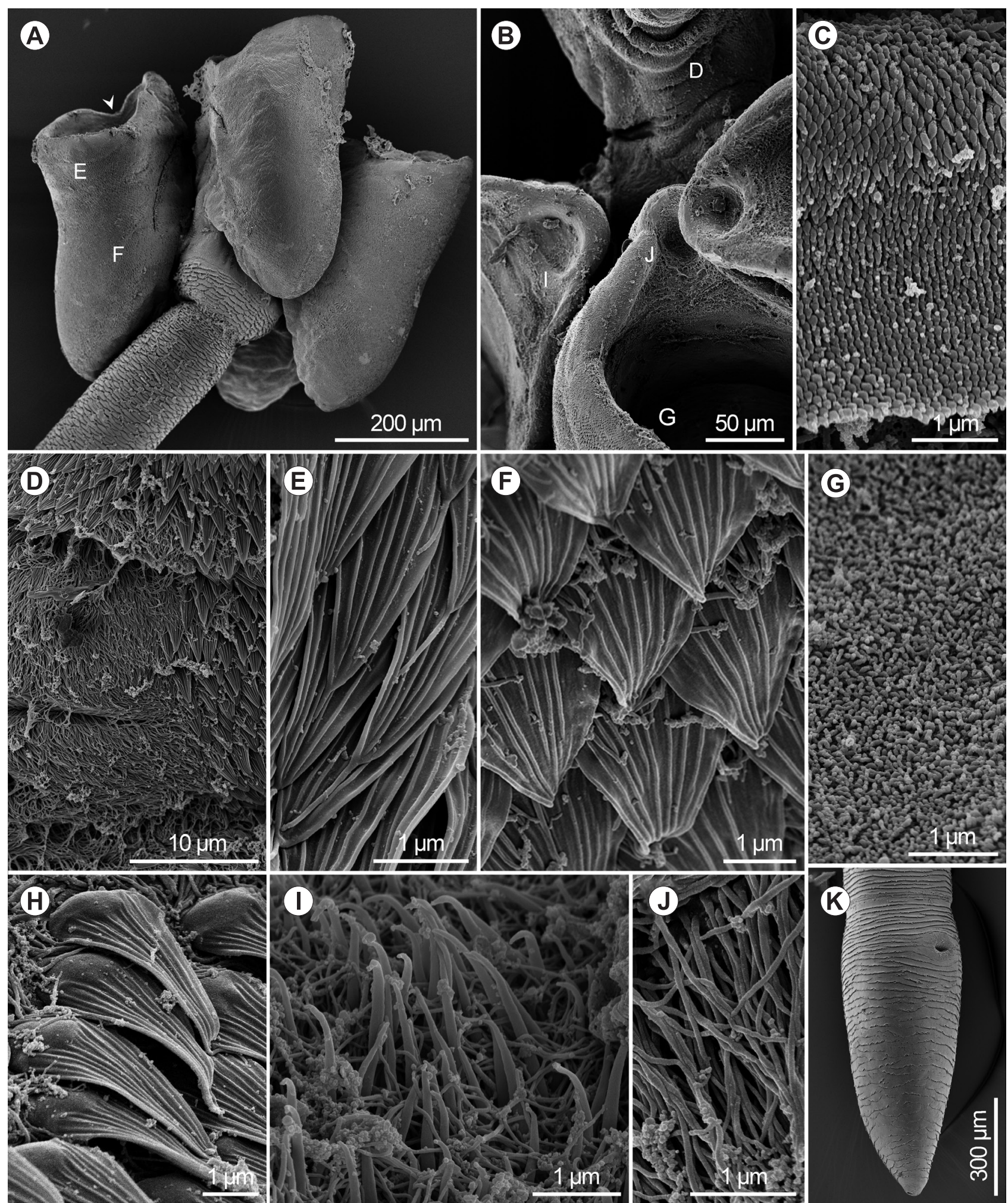

Fig. 3. Guidus francoi sp. n. from Bathyraja magellanica (Philippi), scanning electron micrographs. A - scolex, small letters indicate locations of detail shown in $\mathrm{E}$ and $\mathrm{F}$, arrow indicates marginal indentation; $\mathbf{B}$ - partial apical view of scolex, small letters indicate locations of detail shown in D, G, I and J; C - partial view of strobila scutes; D - surface of bothridial stalk, apical view; $\mathbf{E}$ - proximal bothridial surface near the bothridial rim, wide aristate gladiate spinitriches; $\mathbf{F}$ - proximal bothridial surface in mid-region, wide and short aristate gladiate spinitriches; $\mathbf{G}$ - distal bothridial surface at base of internal cavity, acicular filitriches; $\mathbf{H}$ - detail of aristate gladiate spinitriches showing pad-shaped bases; $\mathbf{I}$ - bothridial rim, narrow gladiate spinitriches and capilliform filitriches; $\mathbf{J}$ - surface of apical sucker, capilliform filitriches; $\mathbf{K}$ - terminal gravid proglottid showing scutes. 
Ovary weakly lobulated, H-shaped in dorsoventral view, tetralobed in cross section, $88-283(179 \pm 51, \mathrm{n}=23)$ long, 100-305 (167 $\pm 54, \mathrm{n}=23)$ wide (Figs. 1E, 2A,D). Vagina thick-walled, essentially straight, surrounded by darkly stained cells distally, extending from ootype region anteriorly, then laterally along anterior margin of cirrus sac to enter atrium anterior to cirrus (Figs. 1E, 2A,C). Genital pores alternate irregularly, $17-38 \%(26 \pm 6, \mathrm{n}=34)$ of proglottid length from anterior margin of proglottid. Vitelline follicles arranged in 2 irregular columns on each lateral margin of proglottid, 16-27 (20 $\pm 4, \mathrm{n}=11)$ long, 19-39 (32 $\pm 5, \mathrm{n}=11$ ) wide, extending from level of genital on aporal side and from level slightly anterior to genital pore on poral side to posterior margin of proglottid, interrupted by terminal genitalia, uninterrupted by ovary; vitelline follicles degenerate in fully gravid proglottids (Figs. 1E, 2A-D). Uterus saccate, restricted to region between ovary and cirrus sac; uterine duct not observed. Osmoregulatory ducts 4, 1 dorsal and 1 ventral pair. Oncospheres arranged in linear cocoons, 229-314 (265 $\pm 44, n=13)$ long, 26-32 $(29 \pm 3, \mathrm{n}=13)$ wide; $7-9(8 \pm 1, \mathrm{n}=26)$ oncospheres per cocoon (Fig. 1B,E,F).

Type host: Bathyraja magellanica (Philippi), Magellan skate (Rajiformes: Arhynchobatidae).

Ty p e locality: Off Río Grande, Tierra del Fuego Province, Argentina (53.9381S, 66.0790W) (host PD10-156).

Additional localities: Off Puerto San Julián, Santa Cruz Province, Argentina (49.4938S, 66.1869W) (hosts PD7105, PD7-107), and Off Río Grande, Tierra del Fuego Province, Argentina (54.5082S, 65.2328W; 54.4033S, 63.9625W; $54.0279 \mathrm{~S}, \quad 67.1134 \mathrm{~W} ; 53.9293 \mathrm{~S}, 67.0834 \mathrm{~W} ; 53.6042 \mathrm{~S}$, 67.6512W) (hosts PD4-001, PD4-025, PD4-097, PD10-017, PD10-070, PD10-071).

Deposited specimens: Holotype MACN-Pa No. 739 (one worm with mature proglottid), eight paratypes MACNPa Nos. 740/1-3, 741/1, 744, 745, 746/1-2 (eight worms with mature proglottids), 12 paratypes MACN-Pa Nos. 740/4, $741 / 2-3,742 / 1-3,743,746 / 3-7$ (12 worms with gravid proglottids), four paratypes IPCAS No. C-887 (four worms with mature proglottids), nine paratypes IPCAS No. C-887 (nine worms with gravid proglottids). Additional specimens (histological sections and specimens prepared for SEM) retained in the personal collection of Adriana Menoret.

Prevalence and intensity of infection: Prevalence $100 \%$ (nine host specimens infected out of nine specimens examined), 15-30 worms per host.

Etymology: This species is named for Franco Donati, the first author's nephew, in honour of his early enthusiasm for skates and sharks.

Remarks. Guidus francoi sp. n. is easily distinguished from the three valid species in the genus based on the scolex, distribution of the vitelline follicles, worm length, and number of testes. In G. francoi the scolex bears stalked bothridia, whereas in the other three species it is composed by sessile bothridia. The vitellarium in G. francoi is distributed in two lateral columns, each two follicles in width, extending anteriorly near the level of the genital pore, whereas the columns are composed by numerous vitelline follicles in width and reach the anterior margin of the pro- glottid in the other three species. In addition, G. francoi is shorter than Guidus antarcticus, Guidus argentinense and Guidus awii (2.9-10.9 mm vs. $140 \mathrm{~mm}, 76-116 \mathrm{~mm}$, and 30-90 mm, respectively) and has fewer testes (42-68 vs. 200-220, 89-153, and 120-150, respectively).

\section{Guidus magellanicus sp. $\mathrm{n}$.}

Figs. 4-6

\section{ZooBank number for species:}

urn:Isid:zoobank.org:act:61D0C9EB-FFD5-49B5-B7A3-FB18FB2E7341

Description (based on eight gravid whole worms, two gravid specimens examined with SEM, and cross sections of mature and gravid proglottids). Worms anapolytic, possessing gravid proglottids, 8.7-15.9 $(12.4 \pm 2.5, \mathrm{n}=8) \mathrm{mm}$ long, maximum width at level of scolex or terminal proglottid (Fig. 4A). Proglottids craspedote, 27-60 (41 \pm 13 , $\mathrm{n}=8$ ) per gravid worm. Scolex composed of scolex proper and 4 stalked bothridia, 475-1,150 $(792 \pm 255, \mathrm{n}=7)$ long, 600-1,075 (790 $\pm 154, \mathrm{n}=8)$ wide (Figs. 4A,B,D,E, 6A). Bothridia globose, conspicuously muscular, 362-829 (544 $\pm 201, \mathrm{n}=7$ ) long, 203-300 (245 $\pm 32, \mathrm{n}=7)$ wide; with anteriorly-oriented apical aperture, continuous muscular sphincter, and apical sucker; anterior bothridial margin indented (Figs. 4A,B,D,E, 6A). Bothridial aperture $112-300(211 \pm 65, \mathrm{n}=6)$ diameter in apical view. Muscular sphincter encircling bothridial aperture, 20-25 (22 \pm 2 , $\mathrm{n}=4)$ thick. Apical sucker, 60-65 $(63 \pm 2, \mathrm{n}=4)$ in diameter (Figs. 4B,D,E, 6C). Stalks short, 38-75 (53 \pm 18 , $\mathrm{n}=4)$ long, 200-290 (230 $\pm 52, \mathrm{n}=4)$ wide (Figs. 4B,D,E, 6A,B). Cephalic peduncle absent. Neck 3,310-6,250 $(4,525 \pm 1,472, n=4)$ long, $112-260(183 \pm 62, n=4)$ wide.

Apex of scolex proper covered with capilliform filitriches (Fig. 6F). Bothridial rim covered with narrow gladiate spinitriches interspersed with capilliform filitriches (Fig. 6I). Proximal bothridial surface covered with wide aristate gladiate spinitriches interspersed with capilliform filitriches, aristate gladiate spinitriches becoming larger more proximally (Fig. 6A,D,E). Distal bothridial surface covered with acicular filitriches (Fig. 6A,H). Apical sucker surface covered with capilliform filitriches (Fig. 6C,G). Stalks covered with aristate gladiate spinitriches interspersed with capilliform filitriches, lacking spinitriches more proximally (Fig. 6B). Capilliform filitriches on neck and strobila arranged in scutes (Fig. 6A,J).

Worms with $20-52(33 \pm 12, \mathrm{n}=8)$ immature proglottids, $1-3(2 \pm 1, \mathrm{n}=8)$ mature proglottids, and 4-9 $(6 \pm 2$, $\mathrm{n}=8$ ) gravid proglottids per worm (Fig. 4A). Mature proglottids wider than long, 265-470 (344 $\pm 81, \mathrm{n}=8)$ long, $520-830(675 \pm 129, \mathrm{n}=8)$ wide, length to width ratio $0.3-0.9(0.5 \pm 0.2, \mathrm{n}=8)$ : 1 . Subterminal gravid proglottids wider than long to longer than wide, 314-670 (479 \pm 141 , $\mathrm{n}=8)$ long, 555-837 (669 $\pm 105, \mathrm{n}=8)$ wide, length to width ratio $0.4-1.2(0.8 \pm 0.2, \mathrm{n}=8)$ : 1 . Terminal gravid proglottid, longer than wide, 810-1,387 (1,049 \pm 197 , $\mathrm{n}=8)$ long, 490-730 (592 $\pm 94, \mathrm{n}=8)$ wide, length to width ratio $1.2-2.8(1.8 \pm 0.6, \mathrm{n}=8): 1$ (Figs. 4A, 5A, $6 J)$. Testes oval, 38-58 (44 $\pm 8, \mathrm{n}=8)$ long, 30-55 (49 \pm 8 , $\mathrm{n}=8)$ wide, arranged in 6-7 columns dorsoventrally and 


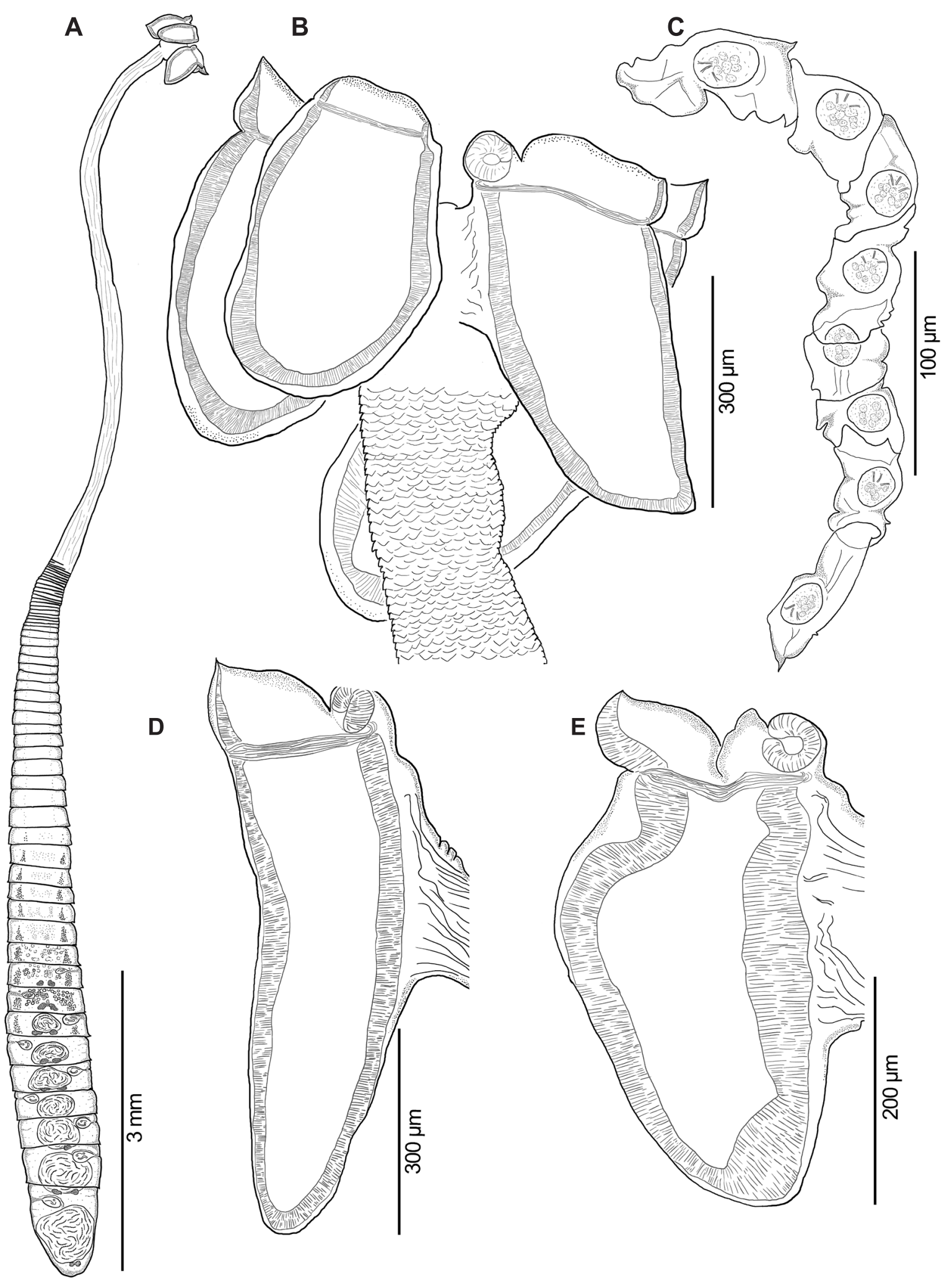

Fig. 4. Guidus magellanicus sp. n. from Bathyraja magellanica (Philippi), line drawings. A - entire gravid worm (holotype MACN-Pa No. 747); B - scolex (holotype MACN-Pa No. 747); C - cocoon; D - bothridium, muscular sphincter relaxed (paratype MACN-Pa No. 748/2); E - bothridium, muscular sphincter contracted (paratype IPCAS No. C-888).

4-5 layers deep in cross section; $71-105(84 \pm 7, \mathrm{n}=8)$ in number, extending from anterior margin of proglottid to the level of ovarian isthmus (Fig. 5A-D). Cirrus sac oval, 140-185 (160 $\pm 15, \mathrm{n}=8)$ long, 70-121 $(90 \pm 21, \mathrm{n}=8)$ wide, cirrus sac length to proglottid width ratio $0.2-0.3$
$(0.2 \pm 0.1, \mathrm{n}=8): 1$. Cirrus covered with minute spinitriches. Vas deferens coiled, extending near anterior margin of proglottid to posterior margin of cirrus sac (Fig. 5A-C).

Ovary weakly lobulated, H-shaped in dorsoventral view, tetralobed in cross section, 82-105 (93 $\pm 11, \mathrm{n}=3)$ long, 
A

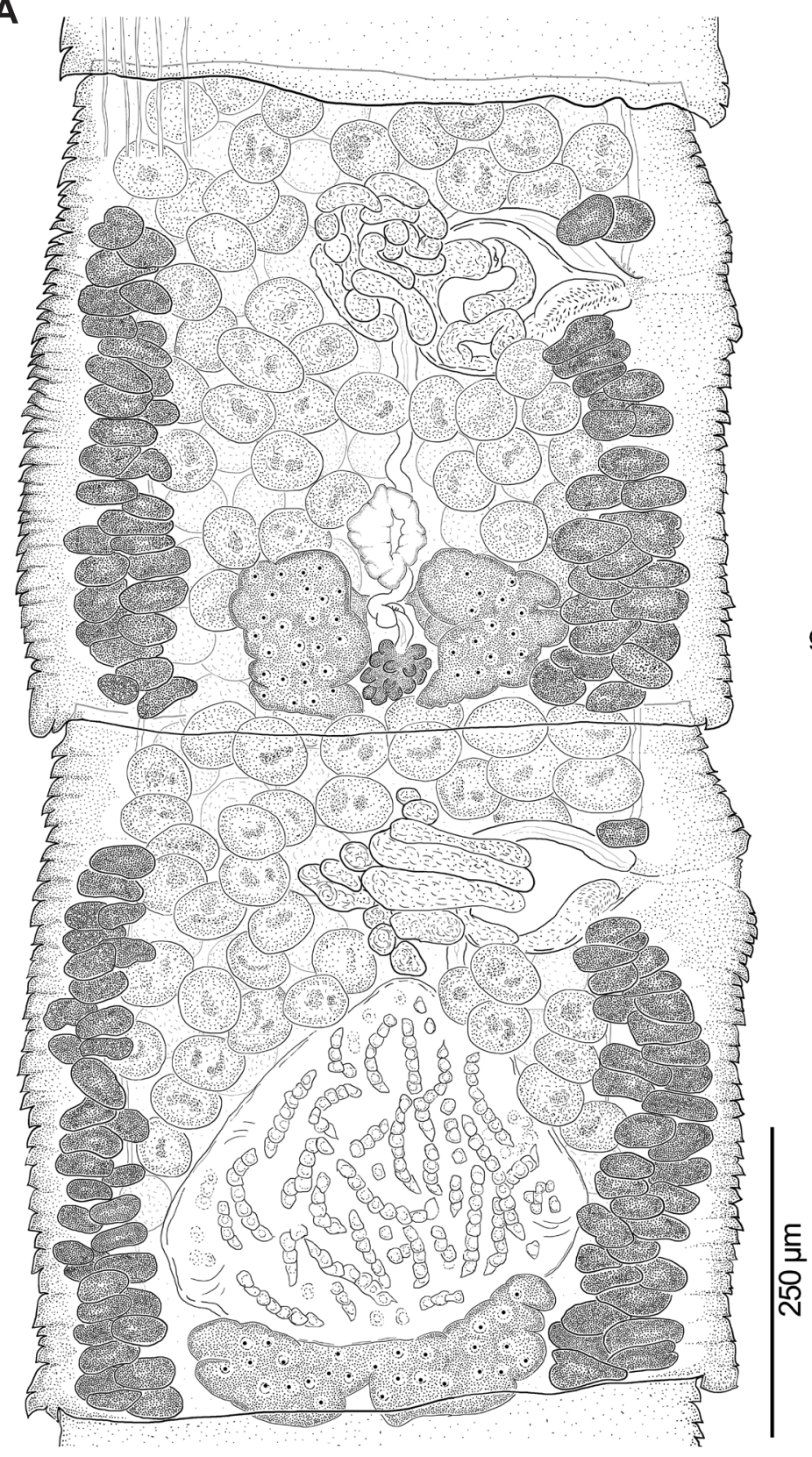

B

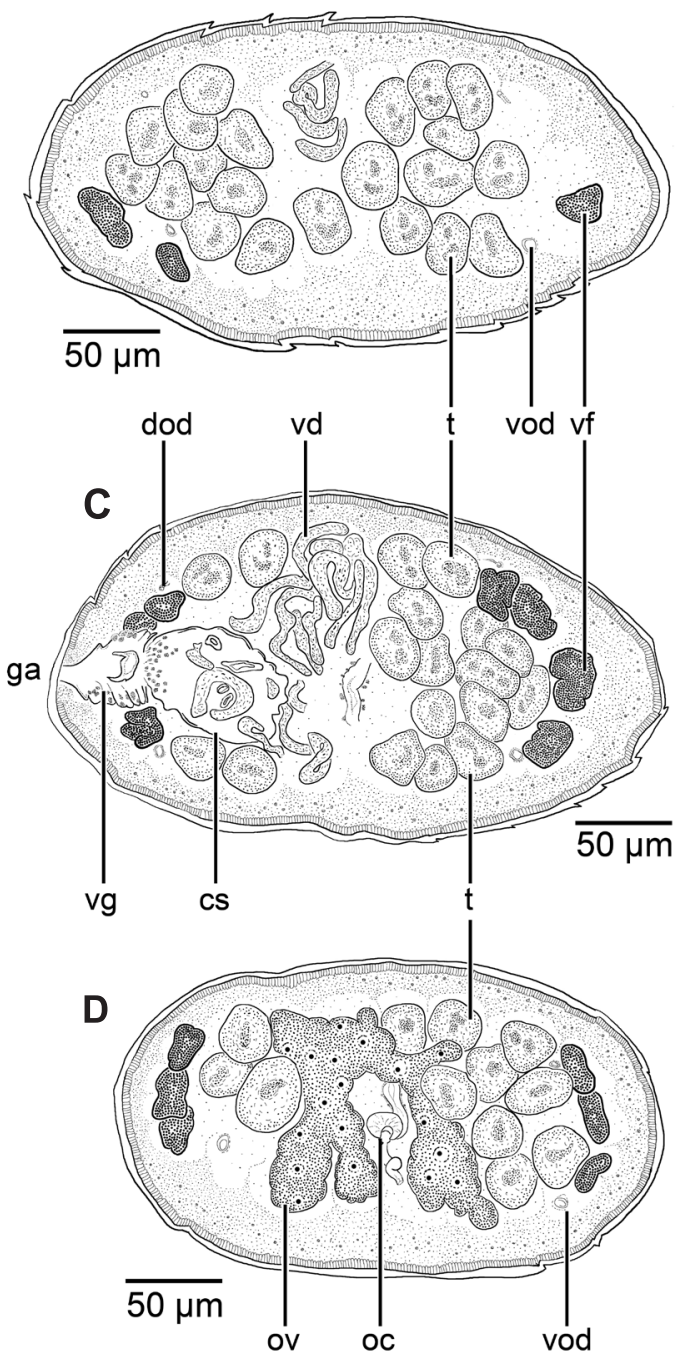

Fig. 5. Guidus magellanicus sp. n. from Bathyraja magellanica (Philippi), line drawings. A-subterminal portion of strobila including mature and gravid proglottids, dorsal view (paratype MACN-Pa No. 748/1); B - cross section of mature proglottid at level of testes anterior to cirrus sac; $\mathbf{C}$ - cross section of mature proglottid at level of genital atrium; $\mathbf{D}$ - cross section of mature proglottid at level of ovarian isthmus. Abbreviations: cs - cirrus sac, dod - dorsal osmoregulatory duct, ga - genital atrium, oc - ovicapt, ov - ovary, $\mathrm{t}-$ testis, vd - vas deferens, vf - vitelline follicle, vg - vagina, vod - ventral osmoregulatory duct.

285-350 (308 $\pm 36, \mathrm{n}=3)$ wide (Fig. 5A,D). Vagina thickwalled, surrounded by darkly stained cells distally, essentially straight, extending from ootype region anteriorly, then laterally along anterior margin of cirrus sac to enter genital atrium anterior to cirrus (Fig. 5A,C). Genital pores alternate irregularly, $31-40 \%(35 \pm 3, \mathrm{n}=6)$ of proglottid length from anterior margin of proglottid. Vitelline follicles arranged in 2 irregular columns on each lateral margin of proglottid, 15-25 (19 $\pm 4, \mathrm{n}=6)$ long, 27-39 (34 \pm 4 , $\mathrm{n}=6$ ) wide, extending from level of genital pore on aporal side and from level slightly anterior to genital pore on poral side to posterior margin of proglottid, interrupted by terminal genitalia, uninterrupted by ovary (Fig. 5A,D). Uterus saccate, restricted to region between ovary and cirrus sac; uterine duct not observed. Osmoregulatory ducts 4, 1 dorsal and 1 ventral pair. Oncospheres arranged in linear cocoons; cocoons 308-314 (311 $\pm 4, \mathrm{n}=12)$ long, 31-33 (32 \pm 1 , $\mathrm{n}=12$ ) wide; 7-8 oncospheres per cocoon (Figs. 4A,C, 5A).

Type host: Bathyraja magellanica (Philippi), Magellan skate (Rajiformes: Arhynchobatidae).

Type locality: Off Río Grande, Tierra del Fuego Province, Argentina (54.0279S, 67.1134W) (host PD4-097). 


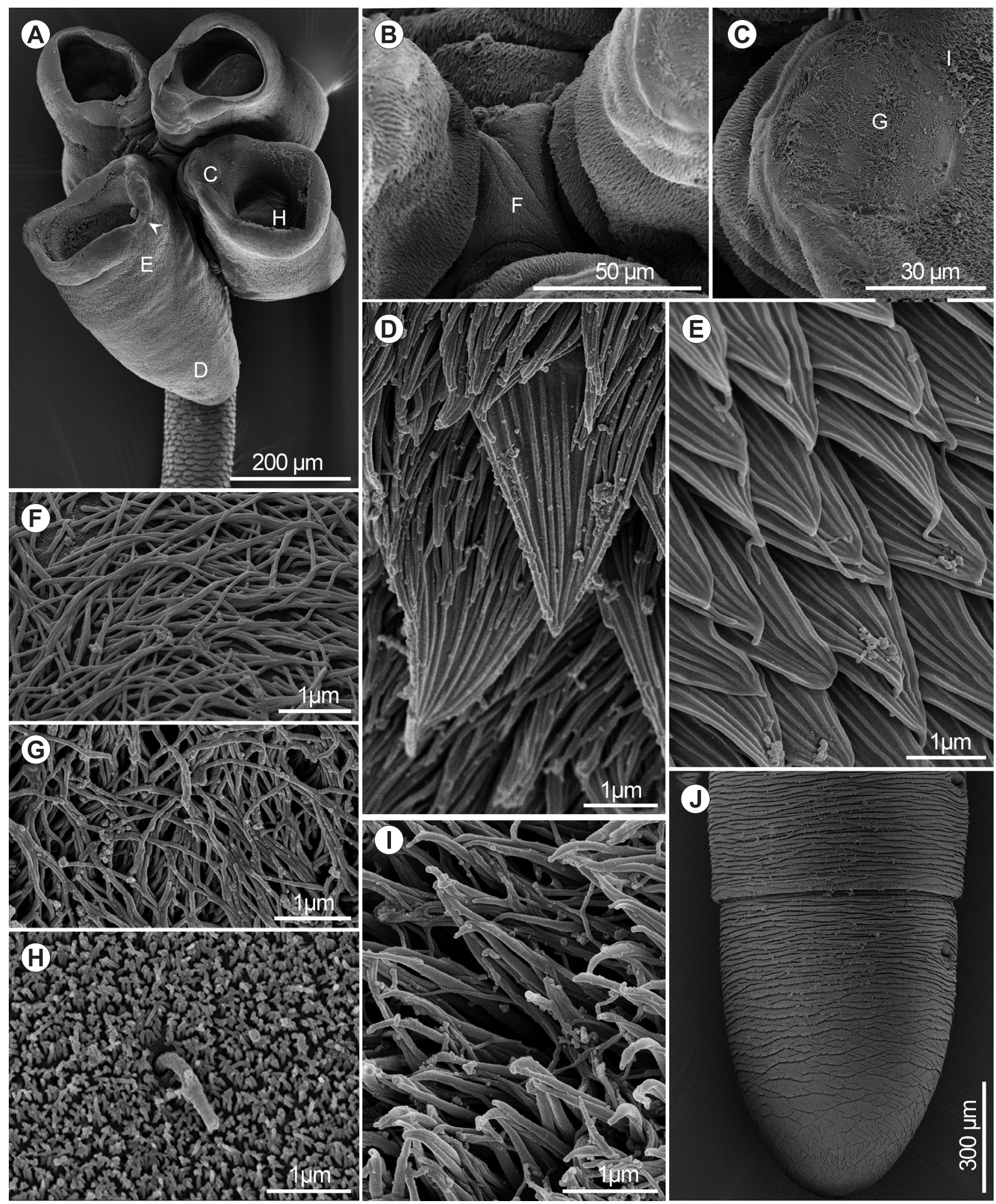

Fig. 6. Guidus magellanicus sp. n. from Bathyraja magellanica (Philippi), scanning electron micrographs. A - scolex, small letters indicate locations of detail shown in $\mathrm{C}-\mathrm{E}$ and $\mathrm{H}$, arrow indicates marginal indentation; $\mathbf{B}$ - partial apical view of scolex showing bothridial stalks, small letter indicates location of detail shown in F; $\mathbf{C}$ - apical sucker, small letter indicates location of detail shown in G; D - proximal bothridial surface near proximal extreme, enlarged wide aristate spinitriches and capilliform filitriches; $\mathbf{E}$ - proximal bothridial surface near bothridial rim, wide aristate spinitriches densely packed; $\mathbf{F}$ - apex of scolex proper, capilliform filitriches; $\mathbf{G}$ surface of apical sucker, capilliform filitriches; $\mathbf{H}$ - distal bothridial surface near base of internal cavity, acicular filitriches and cilium; $\mathbf{I}$ - bothridial rim, narrow gladiate spinitriches and capilliform filitriches; $\mathbf{J}$ - terminal portion of strobila showing scutes. 

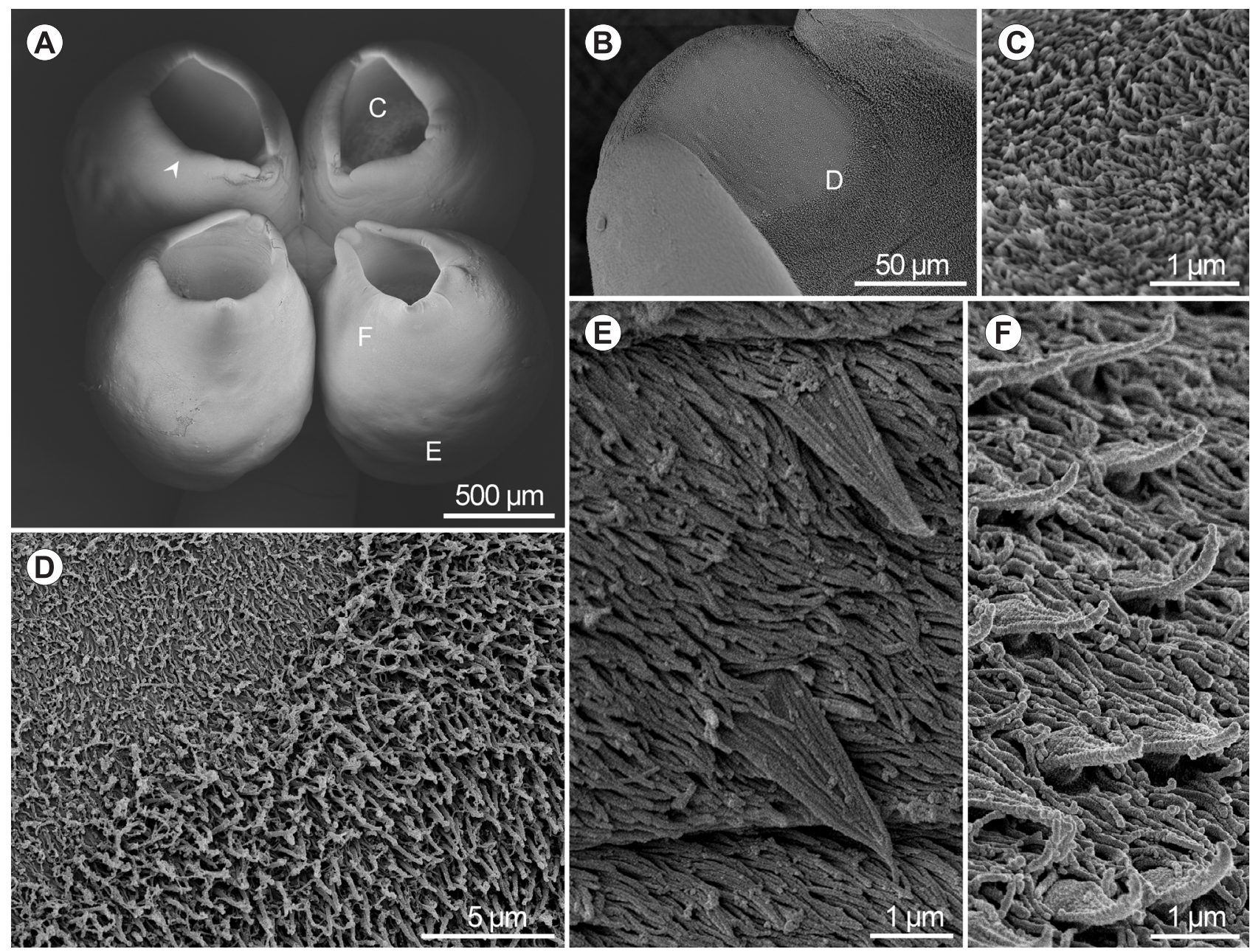

Fig. 7. Guidus argentinense Ivanov, 2006 from Bathyraja brachyurops (Fowler), scanning electron micrographs. A - scolex, small letters indicate locations of detail shown in C, E and F, arrow indicates marginal indentation; $\mathbf{B}$ - apical sucker, small letter indicates location of detail shown in D; C - distal bothridial surface, acicular filitriches; D - detail of apical sucker and surrounding area; $\mathbf{E}$ proximal bothridial surface near proximal bothridial extreme, wide aristate gladiate spinitriches and capilliform filitriches; $\mathbf{F}$ - proximal bothridial surface near apical rim showing wide aristate gladiate spinitriches with pad-shaped bases.

Additional locality: Off Puerto San Julián, Santa Cruz Province (49.4938S, 66.1869W) (host PD7-107).

Site of infection: Spiral intestine.

Deposited specimens: Holotype MACN-Pa No. 747 (one worm with gravid proglottids), four paratypes MACN-Pa Nos. 748/1-2, 749/1-2 (four worms with gravid proglottids), three paratypes IPCAS No. C-888 (three worms with gravid proglottids). Additional specimens (histological sections and specimens prepared for SEM) retained in the personal collection of Adriana Menoret.

Prevalence and intensity of infection: Prevalence $22 \%$ (two host specimens infected out of nine specimens examined), 5-10 worms per host

E ty m o log y: The specific name refers to its distribution along the Magellanic Province in the Argentine Sea.

Remarks. Guidus magellanicus sp. n. is easily distinguished from $G$. antarcticus, $G$. argentinense and $G$. awii by having bothridial stalks rather than sessile bothridia. In G. magellanicus the vitellarium is arranged in two lateral columns, consisting of two follicles in width, extending anteriorly near the level of the genital pore. In contrast, the columns are composed of numerous vitelline follicles in width and reach the anterior margin of the proglottid in $G$. antarcticus, G. argentinense and G. awii. Finally, G. magellanicus has more proglottids per worm than G. francoi (8-24 vs. 27-60, respectively), a higher number of testes (71-105 vs. 42-68, respectively), with testes arranged in more columns in dorsoventral view (6-7 vs. $4-5$, respectively) and in more layers deep in cross section (4-5 vs. 2-3 rows, respectively), and a lower ratio between the cirrus sac length and the proglottid width $(0.2-0.3 \mathrm{vs}$. $0.4-0.6$, respectively).

\section{Guidus argentinense Ivanov, 2006}

Fig. 7

Amended description of the scolex based on two scolices prepared for SEM. Scolex composed of scolex proper and 4 sessile bothridia, lacking apical organ. Bothridia globose, conspicuously muscular with anteriorly-oriented apical aperture, continuous muscular sphincter, and apical sucker; anterior bothridial margin indented (Fig. 7A,B).

Bothridial rim covered with narrow gladiate spinitriches interspersed with capilliform filitriches (Fig. 7D). Proximal bothridial surface covered with wide aristate gladiate spinitriches interspersed with capilliform filitriches; 
aristate gladiate spinitriches becoming less densely packed more proximally (Fig. 7 A,E,F). Distal bothridial surface covered with acicular filitriches (Fig. 7C). Capilliform filitriches on neck and strobila arranged in scutes.

Type host: Bathyraja brachyurops (Fowler), broadnose skate (Rajiformes: Arhynchobatidae).

Type locality: Southwestern Atlantic Ocean, coastal waters off Buenos Aires Province, Argentina at 37.1108S 54.3339W.

Site of infection: Spiral intestine.

Additional localiti es: Off Bahía Blanca, Buenos Aires Province at 39.5713S, 56.2694W (PD3-285) and off the Namuncurá Marine Protected Area/Burdwood Bank at 54.7470S, 59.9476W (PD12-297).

Specimens deposited: Holotype and two paratypes, MACN-Pa No. 432/1-7; one paratype (USNM No. 1393041).

Additional material: two voucher specimens MACNPa Nos. 750, 751 (two strobilae without scolex).

Remarks. The original description of $G$. argentinense is amended to include expanded observations of the scolex (e.g., the presence of a bothridial notch and microtrix morphology of the proximal and distal bothridial surfaces). Guidus argentinense has a shallower bothridial notch than the two species described herein from B. magellanica. The proximal and distal surfaces of the scolex studied for first time in $G$. argentinense exhibit a similar configuration of the microtriches to that observed in G. francoi and G. magellanicus. Capilliform filitriches arranged in scutes on the neck previously mentioned in the original description of $G$. argentinense were confirmed during this study. The distribution of this species is now extended from the known locality off Pinamar in Buenos Aires Province (given as geographic coordinates in the original description) to include Bahía Blanca and southern waters off the Namuncurá Marine Protected Area/Burdwood Bank.

\section{DISCUSSION}

\section{Morphological characters}

Specimens collected from Bathyraja magellanica were recognised as members of Guidus by having most of the diagnostic features of the genus sensu Ivanov (2006), which are revised to accommodate the new species described. Not all species in the genus have sessile bothridia as short bothridial stalks are present in Guidus francoi and Guidus magellanicus. Specimens of Guidus from B. magellanica have bothridia with a marginal indentation which is easily noticeable when the bothridial sphincter is contracted, allowing the formation of a conspicuous projection delimited by the notch (Figs. 1D, 4E) or more slightly perceptible when it is fully relaxed (Figs. 1C, 3A, 4D, 6A). In addition, the presence of this feature was also confirmed in Guidus argentinense (see fig. 4 in Ivanov 2006 and Fig. $7 \mathrm{~A}$ in the present study). In fact, the conspicuous anterior projections in Guidus antarcticus and Guidus awii were defined as lappets by Ivanov (2006). We now include the possession of an indented bothridia as one of the diagnostic features of Guidus, and suggest to not consider the lappets for differentiation of species of Guidus because their pres- ence depends on the contraction of the bothridial sphincter. Similarly, the shape of bothridia can also vary due to the effect of the bothridial muscles. In G. francoi and G. magellanicus they are essentially globose and conical (Figs. 1A-C, 3A, 4A,B,D and 6A) becoming cylindrical when specimens are strongly attached to host tissue (see Figs. $1 \mathrm{D}$ and 4E).

Guidus francoi and G. magellanicus have darkly stained cells surrounding the distal portion of the vagina (Figs. $2 \mathrm{C}, 5 \mathrm{C}$ ) rather than having a vaginal sphincter as in the other three species. Two distinctive configurations of the vitellarium can be recognised among Guidus species. In G. francoi and G. magellanicus it consists of lateral narrow columns, each being two vitelline follicles in width with the field of follicles not reaching the anterior margin of the proglottid. In the other three species of Guidus the columns are broad (with numerous vitelline follicles in width in each column) and extend anteriorly to the anterior margin of the proglottid. Eggs shape among species of Guidus include fusiform and spherical unembryonated eggs, as described in G. argentinense and G. awii, respectively. Additionally, oncospheres are grouped in linear cocoons in G. francoi and G. magellanicus, and are described for the first time in Guidus. Among phyllobothriideans, egg cocoons are also present in Trilocularia eberti Pickering et Caira, 2012.

All three species of Guidus studied with SEM possess filitriches and gladiate spinitriches (aristate or unmodified). The proximal bothridial surface is covered by wide aristate gladiate spinitriches with pad-shaped bases, interspersed with capilliform filitriches. The distal bothridial surface is covered with acicular to capilliform filitriches, and the bothridial rim including the apical sucker is mostly covered with capilliform filitriches. Microtriches on the apex of scolex consist of capilliform filitriches in G. francoi and G. magellanicus, but remain unknown (or probably absent) in $G$. argentinense since microtriches were not observed in that surface in the two scoleces prepared for SEM in the present study.

A great diversity of spinitriches was described among phyllobothriideans and several genera of the order Phyllobothriidea were characterised by having scutes covering the cephalic peduncle, neck and/or strobila (Ivanov 2006, Caira et al. 2020, Maleki et al. 2020). Among them, Scyphophyllidium haselii (Caira, Malek et Ruhnke, 2011) and Scyphophyllidium musculosum (Subhapradha, 1955) partially resemble the three species herein studied in having capilliform filitriches arranged in scutes on the neck and strobila, and gladiate spinitriches (serrate rather than aristate) covering the proximal surface of the globose bothridia, but differ from species of Guidus in the microtriches covering the distal bothridial surface (serrate aristate spinitriches vs. filitriches). Therefore, the homogeneous microtrix pattern exhibited by the three species of Guidus from the Argentine Sea can be useful for differentiating this subset of species from other phyllobothriidean genera.

\section{Distribution patterns}

Despite the cosmopolitan distribution of the order Phyllobothriidea, only a few species have been reported from 
southern latitudes, mainly from coastal waters off Australia (Cutmore et al. 2011, Pickering and Caira 2012, Ruhnke and Workman 2013, Ruhnke et al. 2017, Caira et al. 2020). Particularly, only $10 \%$ of the phyllobothriideans ( 8 out of 81 valid species) belonging to Crossobothrium Linton, 1889, Guidus, Orygmatobothrium Diesing, 1863 and Scyphophyllidium Woodland, 1927 were known so far from the Southwestern Atlantic and adjacent areas (Rocka and Zdzitowiecki 1998, Brooks et al. 1999, Suriano and Labriola 2001, Ivanov 2006, 2008, 2009, Caira et al. 2020).

Among them, the genus Guidus is now known to include G. argentinense, G. awii, G. antarcticus, G. francoi, and $G$. magellanicus with a distribution extending from the Argentine Shelf to Antarctic waters between $37^{\circ} \mathrm{S}-73^{\circ} \mathrm{S}$. Guidus argentinense has the greatest latitudinal range with northern records in the Warm Temperate Southwestern Atlantic Province and the southern distribution boundary in the Magellanic Province. The two new species are also present along the Magellanic Province, whereas G. antarcticus and G. awii are typically distributed in higher latitudes including the Scotia Sea and the Continental High Antarctic Provinces, respectively. However, species of the genus mainly occur in cold-temperate to polar waters of its geographic distribution. Unlike the members of Gui$d u s$, other phyllobothriideans registered at latitudes above $\sim 30^{\circ} \mathrm{S}$ such as Monorygma Diesing, 1863 and Trilocularia Olsson, 1867 also occur in the Northern Hemisphere (Ruhnke 2011, Pickering and Caira 2012).

\section{Host association}

The two new species described from the Argentine Shelf follow the tight host association found among phyllobothriideans. However, all members of Guidus as well as New genus 20 of Ruhnke et al. (2017) exclusively parasitise skates restricted to temperate waters in South America. The description of the new species of Guidus from $B$. magellanica is the second record in the genus parasitising a single host species. Moreover, specimens of B. magellanica caught in the same sampling hauls (hosts PD4-097 and PD7-107) were found simultaneously infected by both G. francoi and G. magellanicus, in contrast to Bathyraja maccaini which was found infected by $G$. antarcticus and G. awii in two different localities. It would be interesting to examine specimens of the Magellan skate along its geographical range to verify if $G$. francoi and $G$. magellanicus remain locally restricted to the southern Magellanic Province despite the wider distribution of their host.

The discovery of G. francoi and G. magellanicus from $B$. magellanica brings the total number of described species in the Southwestern Atlantic from one to three, and increases the number of species in the genus to five. Furthermore, finding these new species contributes substantially to our little knowledge of the cestode fauna in $B$. magellanica, considering that only Acanthobothrium carolinae Franzese et Ivanov, 2020 has previously been reported from that host in the studied area. It is expected that new species will be identified from Bathyraja skates based on the strict specificity exhibited by the members of Gui$d u s$ and the high diversity of arhynchobatids of the genus Bathyraja inhabiting Southwestern Atlantic waters.

Acknowledgements. Special thanks are due to Juan M. Díaz de Astarloa, Ezequiel Mabragaña, and Matías Delpiani from Laboratorio de Biotaxonomía Morfológica y Molecular de Peces (Instituto de Investigaciones Marinas y Costeras-CONICET), and Daniel Bruno from Laboratorio de Ecología, Fisiología y Evolución de Organismos Acuáticos (Centro Austral de Investigaciones Científicas-CONICET) for their help in the identification of hosts collected on board of the RV "Puerto Deseado". Also special thanks to Tomáš Scholz, Editor of Folia Parasitologica, for his good predisposition to attend all our queries, and to the anonymous reviewers for their helpful and insightful suggestions. We also thank Consejo Nacional de Investigaciones Científicas y Técnicas (CONICET) for giving us the chance to work on board of the Oceanographic Vessel "Puerto Deseado". This work has been funded by grants UBACyT 20020130100617BA (2014-2017) from Universidad de Buenos Aires (UBA-Argentina), PIP 11220150100705CO (2015-2017) from CONICET, and PICT 2014 No. 2358 (2015-2019) from Agencia Nacional de Promoción Científica y Tecnológica (ANPCyT-Argentina) to VAI, and PICT 2016 No. 3672 from ANPCyT to AM. This study was conducted under collecting permit No. 39 and No. 260 from the Dirección Provincial de Pesca-Ministerio de Asuntos Agrarios de la Provincia de Buenos Aires, Argentina.

\section{REFERENCES}

Brooks D.R., Marques F., Perroni C., Sidagis C. 1999: Scyphophyllidium uruguayense $\mathrm{n}$. $\mathrm{sp}$. (Eucestoda: Tetraphyllidea) in Mustelus mento (Cope, 1877) (Chondrichthyes: Carcharhiniformes: Triakidae) from La Paloma, Uruguay. J. Parasitol. 85: 490-494.

Caira J.N., Jensen K., Hayes C., Ruhnke T.R. 2020: Insights from new cestodes of the crocodile shark, Pseudocarcharias $\mathrm{ka}$ moharai (Lamniformes: Pseudocarchariidae), prompt expansion of Scyphyophyllidum and formal synonymization of seven phyllobothriidean genera-at last! J. Helminthol. 94: 1-25.

Chervy L. 2009: Unified terminology for cestode microtriches: a proposal from the International Workshops on Cestode Systematics in 2002-2008. Folia Parasitol. 56: 199-230.

Cutmore S.C., Theiss S.M., Bennett M.B., Cribb T.H. 2011: Hemipristicola gunterae gen. n., sp. n. (Cestoda: Tetraphyllidea:
Phyllobothriidae) from the snaggletooth shark, Hemipristis elongata (Carcharhiniformes: Hemigaleidae), from Moreton Bay, Australia. Folia Parasitol. 58: 187-196.

Froese R., Pauly D. (Eds.) 2020: FishBase. World Wide Web electronic publication, www.fishbase.org, 12/2020.

IvAnov V.A. 2006: Guidus n. gen. (Cestoda: Tetraphyllidea), with description of a new species and emendation of the generic diagnosis of Marsupiobothrium. J. Parasitol. 92: 832-840.

IvAnov V.A. 2008: Orygmatobothrium spp. (Cestoda: Tetraphyllidea) from triakid sharks in Argentina: redescription of Orygmatobothrium schmittii and description of a new species. J. Parasitol. 94: 1087-1097.

Ivanov V.A. 2009: New species of Crossobothrium (Cestoda: Tetraphyllidea) from the broadnose sevengill shark, Notorynchus cepedianus, in Argentina. J. Parasitol. 95: 1479-1488. 
Maleki L., Valinasab T., Palm H.W. 2020: A new species of Alexandercestus Ruhnke and Workman, 2013 (Cestoda: Phyllobothriidea) from the sicklefin lemon shark, Negaprion acutidens (Elasmobranchii: Carcharhinidae), in the Gulf of Oman. J. Parasit. Dis. 44: 110-115.

Moghadam F.E., Haseli M. 2019: Orygmatobothrium persiense n. sp. (Cestoda: Phyllobothriidea) from the Arabian smoothhound shark Mustelus mosis (Triakidae) in the Persian Gulf. Acta Parasitol. 64: 288-294.

Pickering M., CAIRA J.N. 2012: A new hyperapolytic species, Trilocularia eberti sp. n. (Cestoda: Tetraphyllidea), from Squalus cf. mitsukurii (Squaliformes: Squalidae) off South Africa with comments on its development and fecundity. Folia Parasitol. 59: 107-114.

Rocka A., Zdzitowiecki K. 1998: Cestodes in fishes of the Weddell Sea. Acta Parasitol. 43: 64-70.

Ruhnke T.R. 2011: A monograph on the Phyllobothriidae (Platyhelminthes, Cestoda). Bulletin of the University of Nebraska State Museum 25: i-xii, 1-208.

Ruhnke T.R., Caira J.N., Pickering M. 2017: Phyllobothriidea Caira, Jensen, Waeschenbach, Olson \& Littlewood, 2014. In J.N. Caira and K. Jensen (Eds), Planetary Biodiversity Inventory (2008-2017): Tapeworms from Vertebrate Bowels of the Earth.
University of Kansas, Natural History Museum, Special Publication no. 25. Lawrence, pp. 305-326.

Ruhnke, T.R., Daniel V., Jensen K. 2020: Four new species of Paraorygmatobothrium (Eucestoda: Phyllobothriidea) from sharks of the Gulf of Mexico and the Atlantic Ocean, with comments on their host specificity. J. Parasitol. 106: 133-156.

Ruhnke T.R., Workman R.E. 2013: Two new species and a new phyllobothriid cestode genus from sharks of the genus Negaprion Whitley (Carcharhiniformes). Syst. Parasitol. 85: 37-48.

Spalding M.D., Fox H.E., Allen G.R., Daviddon N., Ferdaña Z.A., Finlayson M.A.X., Halpner B.S., Jorge M.A., Lombana A., Lourie S.A., Martin K.D., McManus E., MolnaR J., Recchia C.A., Robertson J. 2007: Marine ecoregions of the world: a bioregionalization of coastal and shelf areas. BioSci. 57: 573-583.

Suriano D.M., Labriola J.B. 2001: A new Orygmatobothrium Diesing, 1863 (Eucestoda, Tetraphyllidea) parasite of Mustelus schmitti Springer, 1939 (Carcharhiniformes, Triakidae) from the southewestern Atlantic Ocean. Zoosystema 23: 669-674.

Wojciechowska A. 1991: New species of the genus Phyllobothrium (Cestoda, Tetraphyllidea) from Antarctic batoid fishes. Acta Parasitol. 36: 63-68.

Cite this article as: Menoret A. and Ivanov V.A. 2021: New species of Guidus Ivanov, 2006 (Cestoda: Phyllobothriidea) from Bathyraja magellanica (Philippi) from the Patagonian Continental Shelf of Argentina. Folia Parasitol. 68: 011. 